\title{
Passion and Exploitation Among Young Adults with Different Labor Market Status in Europe
}

I Tuula Bergqvist

PhD, Working Life Science, Karlstad University, Sweden

1 Birgitta Eriksson'

Professor, Working Life Science, Karlstad University, Sweden

\begin{abstract}
The aim of this article is to describe and analyze the relationship between attitudes to work, wellbeing, and labor market status among young adults in Europe and to discuss the extent to which the relationship can be understood in terms of passion or exploitation. This aim is made concrete in the following research questions: To what extent do young adults in Europe have a passionate attitude to work? Are there differences between groups with various labor market status and nationalities? Are there differences in levels of well-being between the groups of young adults with different labor market status, and differences between the countries? The results are based on an individual survey conducted with three categories of young people ( I 8-34 years old): long-term unemployed, those in precarious employments, and those regularly employed. The study had a cross-national comparative design and the countries included were France, Germany, Italy, Poland, Sweden, and Switzerland.
\end{abstract}

\section{KEY WORDS}

Work / passion / exploitation / young adults / long-term unemployment

\section{Background}

n general it can be stated that work is a central feature in most people's lives and work gives them personal satisfaction in addition to the salary. Above all it is the possibility of being able to work and also to fulfill the nonwork time in a satisfactory way that determines whether life is perceived as enjoyable. However, even though we consider work as a provider for satisfaction and fulfillment, we seldom talk about passion in the context of work. Passionate work is most often coupled to intensive positive feelings and pleasure in such work as the work of artists or musicians. Yet, according to Karlsson (2011, 2015), passion is not a general feeling, it has an object. Passion can be considered as consciously accessible positive feelings experienced by engagement in activities such as work-any work-associated with roles that are meaningful for the self-identity. Accordingly, in the context of this article we argue that passion can be considered as orientation to an activity such as work-any work.

A recent Swedish study (Eriksson et al. 2012) showed that $85 \%$ of the labor force answered that they would work even if they did not have to. They had a work-oriented attitude. This means that they expressed positive feelings for and attachment to their

\footnotetext{
${ }^{1}$ E-mail: Birgitta.Eriksson@kau.se
} 
workplace. However, the Swedish study also showed that when work is related to other spheres of life the nonwork-oriented attitude was the dominating one. It was also apparent that the nonwork-oriented attitude was more prevalent among younger than among older people. In this article we are going to account for the attitudes to work among young adults with different labor market status in six European countries: France, Germany, Italy, Poland, Sweden, and Switzerland. What kind of attitudes to work do young adults have? Is it possible to find general patterns between different categories of young adults in different countries or is it the disparities that are prevailing?

In the context of passion we argue that people who only work for money or a salary-having a nonwork-oriented attitude-also have a non-passionate attitude to work. As Karlsson $(2011,2015)$ suggests, the central point with passion is that it has an object, and is directed toward a particular activity. Passion is consciously accessible positive feelings experienced by engagement in activities associated with roles that are meaningful and salient to the self-identity. A nonwork-oriented attitude means that these feelings are directed to the nonwork sphere-a salary being the means for life outside work (Eriksson et al. 2012). Consequently, we argue that a work-oriented attitude is the passionate attitude to work with positive feelings directed to an activity or different activities within the work sphere. Thus, the question to be answered is: Do the young adults in the six European countries have a passionate relationship to work?

In general, a person can be passionate without the passions having anything to do with work, just as a person's well-being does not necessarily have to be connected to work either. However, the alarming figures of youth unemployment in most of the European countries during the recent years can be considered as one of many permanently reproduced inequalities in our societies that affects the young adults' overall wellbeing. When work is so central in people's lives, then being without work becomes a bothersome situation. A large number of studies confirm that losing a job can be a highly stressful experience with limited social contacts, social isolation, and lowered overall wellbeing (e.g., Gallie 2005, Jahoda 1981, 1982, Jahoda et al. [1933] 1971, Kronauer 1998, Nordenmark 1999, Starrin et al. 2001). Hence, in addition to the subordinate exploited position of an employed (Edwards 1986, Karlsson 2011, 2015) we also consider the position of the unemployed at risk to be exploited do to their exclusion from the labor market. Consequently we are interested to find out if there are differences in levels of well-being between the groups of young adults with different labor market status in the six European countries, as well as if there are differences between the countries?

Even though the research field on issues related to work and well-being has during the past years grown to be quite substantial, not enough attention has been paid to the interconnections between attitudes to work, well-being, and the group of young adults with various labor market status in Europe. The aim of this article is to describe the relationship between attitudes to work, well-being, and labor market status among young adults in the six European countries and to discuss the extent to which the relationship can be understood in terms of passion or exploitation.

\section{Theoretical frame}

Our point of departure for definition of the concept of work is in line with that of Karlsson (2015:3): 'the doing of human beings in the sphere of necessity' (cf. Kosík 
1976). Karlsson argues that we work 'when what we do is based on an external necessity to which we must submit in order to secure our existence' (Karlsson 2015:3). For most people work means getting financial resources to live a life as they desire. However, as early as the 1930s Maria Jahoda concluded that in addition to salary, employment fulfills our need for social contacts, regular activities, a time structure, and participation in achieving collective aims (Jahoda et al. [1933] 1971). Accordingly, work means a lot more to people than a salary as we already outlined above-in other words there are a variety of reasons why we value or do not value work. Attitudes to work have been studied by many researchers. To mention some of the precursors in this field, the proliferation of an instrumental attitude among unskilled workers was discussed by John H. Goldthorpe et al. (1968) in the 1960s and some years later argued against by Walter Korpi (1978). In the 1990s several studies concluded that a committed attitude to one's work organization was a common attitude (e.g., Applebaum 1992, Eriksson 1998, Halvorsen 1997, Johansson et al. 1996). In his article we are using the concepts of work-oriented and nonwork-oriented attitudes (Eriksson et al. 2012). Nonwork-oriented attitude is related to the instrumental attitude in that work is the means for life outside the work sphere. Family, hobbies, and recreational activities belong to this nonwork sphere. The work-oriented attitude is related to the committed attitude in that work is more than a salary. Work-oriented individuals express positive feelings for and attachment to their work and workplace. In relation to the nonwork sphere, very important or the most important things in life belong to the work sphere.

In the context of attitudes to work, age is previously known to be a factor that has influence on peoples' work values. The Swedish study (ibid.) showed that the younger the age group, the more the nonwork-oriented attitude. In contrast to this there are earlier studies that report the opposite-the youngest being the most work-oriented (Esser 2005 ) or that the influence of age is very small (Svallfors et al. 2001). In this article the group of respondents as a whole is addressed as young. We are not going to compare different age groups within this group with each other. However, it is interesting to have these previous results in mind while we account for our group of young adults.

The previous results on gender influence on attitudes to work are also contradictory. Some studies (e.g., Johansson 1991) have shown that women report a more nonworkoriented attitude than men, which is opposed to other studies (e.g., Ellingsæter 1995, Eriksson 1998, Hult \& Svallfors 2002, Svallfors et al. 2001) that indicate men having a more nonwork-oriented attitude than women. Furthermore, there are researchers that question if gender has any influence at all in this matter (Gallie et al. 1998, Marsden et al. 1993, Tolbert \& Mohen 1998). However, in this article we are going to focus on the overall gender equality philosophy-how the group of young adults values the relationship between work and gender on a more societal level. It is a well-known fact from gender and work life research that still today the Swedish society (as many other societies) is characterized as a patriarchal society, with male dominance and male dominion (e.g., Bergqvist 2004, Jakobsen 1999, Jónasdóttir 1991, 2003). Men are the norm and women are deviants by not being men (Hirdman 2001). Still today men are seen as the breadwinners and it is women who have the primary responsibility for home and family, even though more men in recent years have begun to share this responsibility (e.g., Bergqvist \& Jakobsen 2012). Thus the overall gender philosophy of the group of young adults and comparisons between how the young men and women value this philosophy shall also shed light on their attitudes to work. 
Having a job-that mostly deals with wage labor-entails a subordinate, exploited position compared to the employer (Edwards 1986, Karlsson 2011, 2015). This exploitation of course forms the implicit foundation of this article although our focus, inspired by Tilly's (1998) durable inequality at the societal level, lies in the structural, societal forces that power over individuals and the absence of their access to resources. People miss having routines, activities, and social networks while being without a job (Jahoda 1981, 1982, Jahoda et al. [1933] 1971). Earlier studies (Nordenmark 1999, Starrin et al. 2001) have shown that it is harder to maintain a meaningful social identity without work, and one may experience difficulties in finding other meaningful social activities to participate in. Being unemployed may lead to a loss of social status, which in turn leads to the development of a feeling of failure. Losing a job puts one at risk of being shifted to the edge of society or even ending up completely outside of it-one becomes socially isolated (Gallie 2005, Kronauer 1998).

Based on these theoretical ideas we formulate the following research questions to fulfill our aim: To what extent do young adults in the six European countries have a passionate attitude to work? Do the levels of well-being differ between the groups of young adults with different labor market status in the six European countries? Are there differences between the countries?

\section{Methodology}

Our presentation is based on data collected in the project 'Youth, unemployment, and exclusion in Europe: A multidimensional approach to understanding the conditions and prospects for social and political integration of young unemployed' (YOUNEX). ${ }^{1}$ The project has a cross-national comparative design and the countries included in the study are France, Germany, Italy, Poland, Sweden, and Switzerland. This article is based on work package 3 in this project, which is an individual survey conducted in 2009-2010, a time period of social and economic instability in Europe. The survey included three categories of young people (18-34 years old) in each country; long-term unemployed, those in precarious employments, and those regularly employed. The category of longterm unemployed involves those who have been without work for at least 12 months. The category of precarious involves those who have had a temporary employment at least once during the same period. Finally, the requirement to be considered regularly employed was at least one year of permanent employment.

The intension was to use polling institutes to carry out the surveys by means of computer-assisted telephone interviews with a random sample of 400 young adults per category and country, and that was basically how it was done. However, in some cases, we were forced to give up either the randomness in the selection process or the planned data collection method. These deviations are reported in each country's national report. There were a total of 7,102 respondents and Table 1 shows the final number in each category and country.

The questionnaire that was used contains questions about social background, attitudes toward work and unemployment, social and political inclusion/exclusion, and well-being. However, in this article we use some selected results in the areas of attitudes to work and well-being. Nevertheless, we start with some information about the respondents' background. 
Table I Number of respondents in each category and country

\begin{tabular}{lccc}
\hline Country & Long-term unemployed & Precarious & Regularly employed \\
\hline France & 405 & 410 & 396 \\
Germany & 329 & 411 & 407 \\
Italy & 480 & 480 & 484 \\
Poland & 396 & 399 & 400 \\
Sweden & 428 & 400 & 399 \\
Switzerland & 304 & 254 & 320 \\
\hline Total & 2,342 & 2,354 & 2,406 \\
\hline
\end{tabular}

Regarding the respondents' social background, there is information about gender, age, education, country of birth, marital status, partnership, parenthood, finances, personal income, and whether they are unemployed, are receiving any benefits or measures, or have ever had a paid job. We can conclude from this perspective that there are major differences between the respondents in different countries and it is difficult to find similarities.

Starting with gender, we can see from Table 2 that there is a significant correlation between labor market status and gender in France, Germany, Italy, and Sweden. This was not observed in Poland and Switzerland. These correlations, however, take different forms. The highest percentage of women is found among those in a precarious position in Italy, Sweden, and Switzerland, whereas in Germany and Poland they dominate in the regularly employed and in France among the long-term unemployed. An unexpected observation is that the proportion of women is higher among the regularly employed in Germany, Italy, and Poland. This suggests that there was a low response rate among employed men in these countries. Since the employment rate is higher among men than women, the expected proportion of women answering the questionnaire should be lower.

Turning to age, we can also see a significant correlation with labor market status in most countries. The exception is France. Here, too, the nature of the correlation differs between countries. The percentage of regularly employed aged 18-24 is lowest in Sweden, Poland, and Germany. This may suggest that the average age for entering the labor market is higher in these countries than in Switzerland, France, and Italy.

Concerning education, there is also a significant correlation with labor market status in all countries with the exception of France. Germany, Poland, Sweden, and Italy have the highest correlation. These correlations indicate that the less secure the connection to the labor market, the greater is the proportion of unskilled young people (those with just a primary/compulsory education) and the more stable the labor market connection the greater the proportion of highly educated people (those with upper secondary education or higher). However, the level of education varies considerably in these countries. The lowest rate of unskilled people is found in Sweden where $12 \%$ of the long-term unemployed, $3 \%$ of the precariously employed, and $2 \%$ of the regularly employed are unskilled. This may be compared with the long-term unemployed in Germany, where the highest level of unskilled people was found $(71 \%)$.

Marital status is another background variable related to labor market status, regardless of the respondent's country. This may be the background variable that showed the most similarities among all countries. In all cases, the highest level of single young 
Table II Percentage women, people between 18 and 24 years and unskilled (those with just a primary/compulsory education)

\begin{tabular}{lccc}
\hline $\begin{array}{l}\text { Gender, age, and education } \\
\text { level/country }\end{array}$ & $\begin{array}{c}\text { Long-term } \\
\text { unemployed }\end{array}$ & Precarious & $\begin{array}{c}\text { Regularly } \\
\text { employed }\end{array}$ \\
\hline Proportion of women & & & 39 \\
France* & 49 & 45 & 57 \\
Germany** & 46 & 53 & 59 \\
Italy** & 52 & 62 & 57 \\
Poland & 53 & 52 & 49 \\
Sweden*** & 51 & 61 & 48 \\
Switzerland & 49 & 56 & 35 \\
\hline Proportion of younger (I8-24 years) people & & & 9 \\
France & 33 & 33 & 50 \\
Germany*** & 14 & 27 & 6 \\
Italy** & 60 & 61 & 4 \\
Poland*** & 38 & 31 & 20 \\
Sweden*** & 45 & 20 & 66 \\
Switzerland*** & 27 & 47 & 24 \\
\hline Proportion of unskilled workers & & & 20 \\
France & 58 & 61 & 5 \\
Germany*** & 71 & 24 & 2 \\
Italy** & 10 & 12 & 15 \\
Poland*** & 23 & 13 & \\
Sweden*** & 12 & 3 & 12 \\
Switzerland*** & 29 & & \\
\hline
\end{tabular}

**** $\mathrm{p} \leq 0.001, * * \mathrm{p} \leq 0.01,{ }^{*} \mathrm{p} \leq 0.05$.

people is found among the long-term unemployed and this is certainly explained by the fact that the percentage of youngest people is highest in this group.

The percentage with a foreign background in the three groups also varies between countries. The greatest difference is seen between long-term unemployed in Poland where there are no citizens from other countries and long-term unemployed in Switzerland where about $50 \%$ are citizens from other countries.

To summarize, when comparing long-term unemployed, precariously employed, and regularly employed young adults in the six European countries in terms of gender, age, education, country of birth, marital status, partnership, parenthood, finances, and personal income, major differences can be observed among people in various countries.

To find out whether the young adults have a passionate attitude to work they were asked to answer to what extent they agreed with four different statements. These were: 'Having a paid work to go to is very important,' 'Unemployment is one of the worst things that can happen to a person,' 'If I won a large sum of money I would stop working immediately,' and 'The most things that happen in life do not involve work.'

To answer the question about the levels of well-being within the group of long-term unemployed young adults in the six European countries we used the following dimensions of well-being: experience of happiness, optimism about the future, and experience of good health in general. Respondents' level of happiness was determined through 
responses to the question 'Taking all things in consideration, how happy would you say you are?' This was measured on a scale of 0 to 10 . People's degree of optimism about their future was by analyzing responses to the question 'Are you rather optimistic or pessimistic about your future?' and the response options were very optimistic, quite optimistic, quite pessimistic, and very pessimistic. Answering very or quite optimistic indicates a high level of well-being. The respondents' health in general was captured by using a part of the General Health Questionnaire developed by Goldberg (1972). This is an additive index based on different statements about strain, self-confidence, and the ability to structure one's everyday life. The number of statements varies between different studies, such as 30, 20, or 12. In this study, like Nordenmark (1999) we used 12 different statements. In our version, the values vary from 0 to 36 ; the higher the score, the higher the person's well-being.

\section{Results}

In this section we will present the results regarding the relationship between having a passionate attitude to work as well as being exploited and labor market status among young adults in six European countries.

\section{Attitudes about work and unemployment}

Initially, some results on attitudes to work and unemployment in general as well as attitudes to work and employment from a gender perspective are presented. The respondents were asked to answer to what extent they agree with various statements about work and unemployment taken from the work involvement scale proposed by Nordenmark (1999). The results from four of the statements are presented in Table 3 where the figures show the percentage of those who agree with these statements.

Most young people in the six European countries seem to be of the opinion that having a paid work is very important. The exceptions are all categories in Poland and the long-term unemployed in Sweden. In most countries the regularly employed value work the most. Correspondingly, there were far fewer who answered that they would stop working immediately if they won a large sum of money. As we see in the table, the proportion who agrees with this statement varies between 13 and 30\% except in France where the levels are higher. These results are in line with a new Swedish study which shows that most people who have actually won a large sum of money did not change their relation to work; they did not stop working, they did not take an extra time off, and they did not cut their working hours to any great extent (Hedenus 2011).

If we focus on the answers from the group of long-term unemployed we can conclude that an overwhelming majority of the unemployed young people agreed that having a paid job is very important. This is valid also for Poland and Sweden even though the levels of agreement with this statement in these two countries are somewhat lower. Germany, Italy, and Sweden had the highest number who agreed that being unemployed is one of the worst things that can happen to a person. Only $20-24 \%$ of the unemployed in most of the countries would stop working if they won a large sum of money. Here the exceptions are Sweden and France where 30 and 54\%, respectively, would do so. 
Table III Percentages of those who agreed with different statements regarding work and unemployment

\begin{tabular}{|c|c|c|c|}
\hline Statements/Country & $\begin{array}{l}\text { Long-term } \\
\text { unemployed }\end{array}$ & Precarious & $\begin{array}{l}\text { Regularly } \\
\text { employed }\end{array}$ \\
\hline \multicolumn{4}{|c|}{ Having paid work to go to is very important } \\
\hline France & 91 & 90 & 89 \\
\hline Germany & 95 & 93 & 96 \\
\hline Italy*** & 90 & 93 & 96 \\
\hline Poland** & 76 & 82 & 86 \\
\hline Sweden*** & 76 & 93 & 96 \\
\hline Switzerland & 96 & 94 & 96 \\
\hline \multicolumn{4}{|c|}{$\begin{array}{l}\text { Unemployment is one of the worst things that } \\
\text { can happen to a person }\end{array}$} \\
\hline France & 53 & 55 & 49 \\
\hline Germany* & 72 & 62 & 67 \\
\hline Italy & 70 & 72 & 77 \\
\hline Poland $* * *$ & 59 & 67 & 73 \\
\hline Sweden*** & 74 & 50 & 55 \\
\hline Switzerland** & 53 & 40 & 47 \\
\hline \multicolumn{4}{|c|}{$\begin{array}{l}\text { If I won a large sum of money I would stop } \\
\text { working immediately }\end{array}$} \\
\hline France & 54 & 54 & 56 \\
\hline Germany** & 23 & 13 & 20 \\
\hline Italy*** & 21 & 18 & 28 \\
\hline Poland & 20 & 18 & 13 \\
\hline Sweden*** & 30 & 17 & 18 \\
\hline Switzerland** & 24 & 16 & 30 \\
\hline \multicolumn{4}{|c|}{$\begin{array}{l}\text { The most important things that happen in life do } \\
\text { not involve work }\end{array}$} \\
\hline France & 50 & 55 & 53 \\
\hline Germany* & 30 & 38 & 40 \\
\hline Italy** & 29 & 27 & 20 \\
\hline Poland & 50 & 51 & 49 \\
\hline Sweden** & 37 & 46 & 45 \\
\hline Switzerland & 51 & 42 & 51 \\
\hline
\end{tabular}

**** $\mathrm{p} \leq 0.001, * * \mathrm{p} \leq 0.01, * \mathrm{p} \leq 0.05$.

In France, Poland, and Switzerland about half of the respondents say that the most important things that happen in life do not involve work. The figures concerning this statement were much lower in the other countries.

An interpretation of these results is that paid work is very important for all categories of young people. This is consistent with previous research on attitudes to work among young people as well as adults (e.g., Applebaum 1992, Eriksson et al. 2012, Halvorsen 1997, Johansson et al. 1996). The long-term unemployed in Germany and Italy have the most work-oriented-passionate-attitude to work followed by those in Sweden and Switzerland, while this attitude is the least widespread among the long-term unemployed in France and Poland. 
What is it about a job that is valued so highly? The questionnaire contained a question about the values young people mainly attribute to work. The respondents were asked to value aspects like salary, regular activities, social contacts, status and identity, and personal development. An overall result is that all aspects are important which is in line with Marie Jahoda's thesis on the latent functions of work (Jahoda 1982). She believes that in addition to a salary, work has five latent functions that few or no other institutions in society can provide. First, work gives us a special sense of time. Second, it broadens our social horizons beyond the family, our circle of friends, and the immediate neighborhood. Third, we have an anchor in a community whose strength exceeds our own. Fourth, it provides us with work status and identity. Fifth and finally, we are forced by work to perform acts whose purpose lies beyond personal aims. A more detailed comparison between countries shows that among unemployed in Germany, Sweden, and Switzerland personal development was the most important aspect of a job. In France, Italy, and Poland salary was most important.

Participants' attitudes toward work and employment from a gender perspective were captured by asking the respondents to use a scale of 0 to 10 to indicate how important they think it is for a woman and a man, respectively, to have a paid job in order to be considered an adult.

Regarding the importance of work as an entrance ticket to adulthood, it is clear from Table 4 that people in all categories ranked its importance higher for men than for women.

Table IV The importance of having a job for women and men to be considered as adults (average based on a scale of 0 to 10 )

\begin{tabular}{|c|c|c|c|}
\hline Importance of having a job/Country & $\begin{array}{l}\text { Long-term } \\
\text { unemployed }\end{array}$ & Precarious & $\begin{array}{l}\text { Regularly } \\
\text { employed }\end{array}$ \\
\hline \multicolumn{4}{|l|}{ For a woman to be considered an adult } \\
\hline France $\left(\mathrm{Eta}^{2}=0.002\right)$ & 7.2 & 7.1 & 7.0 \\
\hline Germany $\left(\mathrm{Eta}^{2}=0.010 * *\right)$ & 6.4 & 5.7 & 5.8 \\
\hline Italy $\left(\mathrm{Eta}^{2}=0.008 * *\right)$ & 7.1 & 7.1 & 6.6 \\
\hline Poland $\left(\mathrm{Eta}^{2}=0.002\right)$ & 5.4 & 5.6 & 5.4 \\
\hline Sweden $\left(\operatorname{Eta}^{2}=0.018 * * *\right)$ & 5.1 & 4.3 & 4.0 \\
\hline Switzerland $\left(\mathrm{Eta}^{2}=0.025^{*} * * *\right)$ & 7.1 & 6.0 & 6.4 \\
\hline \multicolumn{4}{|l|}{ For a man to be considered an adult } \\
\hline France $\left(\mathrm{Eta}^{2}=0.006 *\right)$ & 7.9 & 7.7 & 7.6 \\
\hline Germany $\left(\operatorname{Eta}^{2}=0.025 * * *\right)$ & 8.0 & 7.0 & 7.0 \\
\hline Italy $\left(\mathrm{Eta}^{2}=0.002\right)$ & 7.5 & 7.6 & 7.4 \\
\hline Poland $\left(\operatorname{Eta}^{2}=0.000\right)$ & 6.9 & 6.9 & 7.0 \\
\hline Sweden $\left(\operatorname{Eta}^{2}=0.039 * * * *\right)$ & 5.5 & 4.6 & 4.2 \\
\hline Switzerland $\left(\mathrm{Eta}^{2}=0.025 * * *\right)$ & 8.0 & 6.7 & 7.0 \\
\hline
\end{tabular}

**** $\mathrm{p} \leq 0.001$, ** $\mathrm{p} \leq 0.01$, * $\mathrm{p} \leq 0.05$.

A job is not as important for a woman to be seen as an adult as it is for a man. In almost all countries, the long-term unemployed valued work higher as a criterion for adulthood than those in other categories. Although the patterns above are general, some differences between the countries can be found, even though they are small. One is the 
level of the importance. Women working are consistently ranked as more important in France, Italy, and Switzerland than in Germany, Poland, and Sweden. When it comes to men, the importance of work for entering adulthood was highly valued in all countries except Sweden. Sweden stands out when it comes to this issue. Compared with the other countries, the lowest percent who perceive work as an indicator for adulthood can be found here. This is in line with previous research claiming that when it comes to work orientation and gender, attitudes among individuals from the Nordic countries deviate from other countries in Europe (European Social Survey 2010).

Separate analyses for women and men, not presented in the above table, have been conducted regarding the importance of work and adulthood. The results indicate that women in all countries and in all categories regard work as important for an entrance into adulthood to a greater extent than men. This is valid when considering the importance of work for women as well as men.

\section{Well-being}

Regarding happiness, in Table 5 one can see a clear pattern that occurred in all countries. The stronger one's connection to the labor market, the more likely it is that he or she is happy and vice versa; the weaker the relation to labor market, the less likelihood

Table $\mathbf{V}$ Happiness (average based on a scale of 0 to 10, optimism (percentage of those who are very or quite optimistic about the future), and health (average based on a scale from 0 to 36) among different categories of young adults in different countries

\begin{tabular}{lccc}
\hline Dimension of well-being/country & $\begin{array}{c}\text { Long-term } \\
\text { unemployed }\end{array}$ & Precarious & $\begin{array}{c}\text { Regularly } \\
\text { employed }\end{array}$ \\
\hline Happiness & 3.5 & 4.9 & 7.8 \\
France**** & 6.0 & 7.6 & 7.8 \\
Germany**** & 6.8 & 7.4 & 7.5 \\
Italy**** & 7.3 & 7.7 & 8.0 \\
Poland**** & 5.8 & 7.7 & 8.0 \\
Sweden*** & 7.0 & 7.9 & 8.1 \\
Switzerland*** & & & \\
\hline Optimism about the future & 73 & 75 & 87 \\
France**** & 75 & 87 & 87 \\
Germany*** & 69 & 78 & 79 \\
Italy**** & 86 & 91 & 95 \\
Poland**** & 62 & 90 & 94 \\
Sweden*** & 82 & 86 & 89 \\
Switzerland**** & & & \\
\hline Experience of generally good health & 26 & 28 & 27 \\
France**** & 25 & 30 & 30 \\
Germany*** & 25 & 26 & 26 \\
Italy*** & 28 & 30 & 31 \\
Poland* & 20 & 29 & 28 \\
Sweden**** & 26 & 27 & \\
Switzerland* & & & \\
\hline
\end{tabular}

**** $\mathrm{p} \leq 0.001$, ** $\mathrm{p} \leq 0.01,{ }^{*} \mathrm{p} \leq 0.05$. 
of experienced happiness. The differences are particularly significant between the longterm unemployed and the members of the other two groups. In the latter case, France differs from the other countries. The group of precariously employed young adults in France is closer to the group of unemployed than to the employed. One may interpret this to mean that having a job, even a temporary one, is always better for well-being than being among the long-term unemployed. One particular difference between the countries is the level of happiness, especially when it comes to the unemployed. The highest levels of happiness in this group are found in Switzerland and Italy and the lowest levels are found in Sweden and France.

Concerning the level of optimism about the future the same pattern applies: The stronger the connection to the labor market, the greater the proportion of those who are optimistic about the future. We can also see that the percentage of optimists within the groups of the precariously employed and the employed are rather similar to those of the long-term unemployed. France is an exception in this respect too. A comparison of the countries shows that the greatest differences are found in the group of long-term unemployed, with the highest level of optimism in Poland and the lowest in Sweden.

With regard to health in general, the pattern noted for previous aspects is repeated here. Sweden stands out with the highest healthy rating in the group of employed, and the lowest healthy rating in the group of unemployed.

To summarize, one can see that a similar pattern is dominant in all countries. The stronger the connection to the labor market, the more likely it is that one feels happy and optimistic about the future and that his or her health is good, and vice versa-the weaker the link to the labor market, the less likelihood of happiness, optimism, and health. The differences are particularly large when one compares responses of those in the long-term unemployed group and those in other groups. However, this does not mean that most long-term unemployed people are unhappy, pessimistic, and unhealthy. On the contrary, even this group reports high or average levels of well-being, that is, most of them are happy, optimistic, and healthy. The potential interpretation of this is that they have other objects of positive feelings to compensate for the exploited position of unemployment.

\section{Concluding discussion}

Overall, the results of this study point out that the young adults in France, Germany, Italy, Poland, Sweden, and Switzerland are not a homogenous group. However, the results show several common tendencies in attitudes to work between the different categories of young adults and especially some general patterns in terms of passion and exploitation.

We can conclude that a paid job is very important for young people in all categories. An overall result shows that all aspects of work-like salary, regular activities, social contacts, status and identity, and personal development-are important. Even though there are small differences between the three categories in the six countries, the results demonstrate that having a paid job is very important, and only a minority answered that they would stop working immediately if they won a large sum of money. Further, the young adults in all categories reported that it is more important for men than for women to have a job, and that it is more important for men than for women to have a job to be 
considered as an adult. This is strongly in line with the previous research showing how men are seen as the breadwinners with financial responsibilities and it is women who are seen as responsible for home and family-quite concern raising results about their gender equality philosophy.

Turning to the context of passion, we wanted to find out if young adults in the six European countries have a passionate attitude to work. According to our results-yes, the majority of the young adults in the six European countries have a passionate workoriented attitude to work. The majority of the young adults appreciate work in various ways. The above-mentioned aspects of regular activities, social contacts, status and identity, and personal development express their positive-passionate-feelings and attachment to work. The fact that women in all countries and in all categories regard work as important for an entrance into adulthood to a greater extent than men, indicate that women have a more passionate relationship to work that men. Further, the majority in almost all groups mean that the most important things in life do involve work. This is in contrast to the Swedish study (Eriksson et al. 2012) that showed opposite results; when work is related to other spheres of life the nonwork-oriented attitude is the dominating one. This difference might be dependent on the fact that in our study the proportion of young adults-18-24 years, just out of school and single-is quite large, around $50 \%$ in both of the categories of unemployed and precarious and they do not have the same kind of social relations in their nonwork sphere as those with families. Thus the centrality of work in their lives becomes more apparent. Consequently, our results suggest that it is not age per se that determines attitudes to work; instead the decisive seems to be age in combination with life situation. Although we have found patterns regarding attitudes in all countries, there are differences within this group of young adults and between countries that need to be examined more thoroughly and on the national level.

Regarding the work-oriented attitude being the passionate attitude to work, we believe that some caution should be taken in interpreting the nonwork-oriented attitude as a non-passionate attitude to work. The non-passionate attitude does not necessarily mean that an individual totally lacks passion for work; nevertheless a person's different passions are being more widely spread within both work and nonwork spheres compared to those with work-oriented attitudes. This could be described as the hierarchy arranging an individual's meaningful identities connected to different roles in the life of the person in question (Karlsson 2011, 2015), directing passion for the nonwork sphere higher up in this hierarchy than passion for the work sphere. Consequently, we do not argue that there is no passion connected to a nonwork-oriented attitude, yet cautiously, we can conclude that individuals with a nonwork-oriented attitude are less passionate for work than those with a work-oriented attitude.

As accounted above, the group of long-term unemployed does not differ from the other two groups in attitudes to work-all groups have a passionate, work-oriented attitude. A comparison between countries shows that the long-term unemployed in Germany and Italy are the most work-oriented, followed by those in Sweden and Switzerland. This passionate attitude is least widespread among the long-term unemployed in France and Poland, nevertheless more widespread than non-passionate attitude. Hence, the centrality of work in the everyday lives of these young adults is evident, and as earlier research confirms (e.g., Gallie 2005, Jahoda 1982, Jahoda et al. [1933] 1971, Kronauer 1998, Nordenmark 1999, Starrin et al. 2001) being without work that forms such a central part of one's life, becomes a bothersome situation. This absence of work becomes visible 
in that the unemployed, in general, report the lowest levels of well-being compared to the categories of employed and precarious.

Based on our results we can conclude that having a job is always better for well-being than being among the long-term unemployed. This is true even if it is just temporary in a precarious situation. However, we need to remember that not all of the unemployed report low levels of well-being and that the differences between groups are not that remarkable. The majority of the long-term unemployed are happy, optimistic, and healthy. As Nordenmark (1999) points out the experience of unemployment can be positively affected by social support from friends and family and from the social networks one has outside the workplace. Still, an interesting and quite alarming finding, at least from a Swedish perspective, is that well-being is the worst among long-term unemployed young adults in Sweden. Unfortunately we do not have enough empirical data to clarify the reason for this, yet a possible explanation could be that quite a large portion of individuals ending up in the group of long-term unemployed in Sweden are individuals with various disabilities or a deviant life situation due to which the risk for stigmatization is more prevalent. Thus more research is needed to obtain more knowledge in this matter.

The last question to discuss is the relationship to exploitation of the group of unemployed young adults. It is quite obvious that this group is to be considered as exploited in the sense that they do not have access to resources-resources partly being of financial or social nature that an employment can provide. Consequently, they are also cut off from their passions through not having access to work-related activities. Yet, most of them report high or average levels of well-being and do not differ from individuals in the other groups in a significant way. The potential interpretation of this is that they have other objects of positive feelings-passions-to compensate for the lack of work. Thus it is not the exploited structural position of unemployment as such that determines the well-being of an individual; it is the individual resources, for example, nonwork-related activities and social contacts, which are crucial. The most alarming result is that there seems to be a group of unemployed young adults—although a minority of them-that are lacking sources of positive feelings in their lives in general.

\section{References}

Applebaum, H. (1992) The Concept of Work. Ancient, Medieval, and Modern. Albany: State University of the New York Press.

Bergqvist, T. (2004) Siälvständighetens livsform(er) och småföretagande tillämpning och utveckling av realistisk livsformsanalys. [Independent Life Mode(s) and Small FirmsApplication and Development of Realist Life Mode Analysis.] Karlstad: Karlstad University Press.

Bergqvist, T. \& L. Jakobsen (2012) 'Att kombinera arbete i räddningstjänst med resten av livet' [Combining Rescue Service Work with Non-Work Time], in L. Jakobsen, C. Krekula \& L.G. Eriksson (eds): Jämställdhet, mångfald och svenska räddningstjänster. Om föreställningar och förändringsvilior. [Equality, Diversity and the Swedish Rescue Services. Conceptions and Willingness to Change.] Karlstad: Karlstad University Press.

Edwards, P. K. (1986) Conflict at Work. A Materialist Analysis of Workplace Relations. London: Basil Blackwell.

Ellingsæter, A.-L. (1995) Gender, Work and Social Change. Beyond Dualistic Thinking. Report 95: 14. Oslo: Institute for Social Research. 
Eriksson, B. (1998) Arbete i människors liv. [Attitudes to Work.] Department of Sociology, Göteborg University.

Eriksson, B., J. Karlsson \& T. Bergqvist (2012) 'Development of Work Orientations in Sweden', in B. Furåker, K. Håkansson \& J. Ch. Karlsson (eds): Commitment to Work and Job Satisfaction. Studies of Work Orientations. London: Routledge.

Esser, I. (2005) Why Work? Comparative Studies on Welfare Regimes and Individuals' Work Orientations. Department of Sociology, Stockholm University.

European Social Survey (2010) ESS Round 5. London: Centre for Comparative Social Surveys, City University London.

Gallie, D., M. White, Y. Cheng \& M. Tomlinson (1998) Welfare Regimes and the Experience of Unemployment Relationship. Oxford: Oxford University Press.

Gallie, D. (2005) 'Unemployment, Marginalization Risks and Welfare Policy', in Gallie, D. (ed.): Resisting Marginalization. Unemployment Experience and Social Policy in the European Union. Oxford: Oxford University Press, pp. 1-33.

Goldberg, D. P. (1972) The Detecting of Psychiatric Illness by Questionnaire-A Technique for the Identification and Assessment of Non-psychotic Psychiatric Disease. Oxford: Oxford University Press.

Goldthorpe, J. H., D. Lockwood, F. Bechhofer \& J. Platt (1968) The Affluent Worker: Industrial Attitudes and Behaviour. Cambridge: Cambridge University Press.

Halvorsen, K. (1997) 'The Work Ethic under Challenge? Cause or Effect of Marginality to the Labour Market', in J. Holmer and J. Ch. Karlsson (eds) Work-Quo Vadis? Aldershot: Ashgate, pp. 119-149.

Hedenus, A. (2011) At the End of the Rainbow-Post-winning Life among Swedish Lottery Winners. Gothenburg: Studies in Sociology No 45, University of Gothenburg.

Hirdman, Y. (2001) Genus—om det stabilas föränderliga former. [Gender-About the Changing Forms of the Stable.] Malmö: Liber AB.

Hult, C. \& S. Svallfors (2002) 'Production Regimes and Work Orientations: A Comparison of Six Western Countries’. European Sociological Review, 3(18): 315-331.

Jahoda, M. (1981) 'Work, Employment, and Unemployment'. American Psychologist, 36: 184-191.

Jahoda, M. (1982) Employment and Unemployment. A Social-Psychological Analysis. Cambridge: Cambridge University Press.

Jahoda, M., Lazarsfeld, P. F. \& Zeisel, H. ([1933] 1971) Marienthal: The Sociography of an Unemployed Community, London: Tavistock.

Jakobsen, L. (1999) Livsform, kön och risk. En utveckling och tillämpning av Realistisk livsformsanalys. [Life mode, Gender and Risk. Development and application of Realist Life Mode Analysis.] Lund: Arkiv.

Johansson, M. (1991) 'Lönearbete som mål eller medel' [Wage Labor, as a goal or a means], in B. Furåker (ed.): Arbetets villkor. [The Conditions of work.] Lund: Studentlitteratur, pp. 175-195.

Johansson, G. et al. (1996) 'Drivkrafter för arbete—attityder och värderingar i arbetskraften' [Incentives to work - attitudes and values in the labor force], in SOU 1996: 34 Aktiv arbetsmarknadspolitik. Expertbilaga. Stockholm: Fritzes.

Jónasdóttir, A. G. (1991) Love Power and Political Interests. Towards a Theory of Patriarchy in Contemporary Western Societies. (Örebro Studies 7). Örebro: Högskolan.

Jónasdóttir, A. G. (2003) Kärlekskraft, makt och politiska intressen. En teori om patriarkatet $i$ nutida västerländska sambällen. [Love Power and Political Interests. A Theory of Patriarchy in Contemporary Western Societies.] Göteborg: Daidalos.

Karlsson, J. Ch. (2011) 'Arbete, passion, exploatering' [Work, Passion, Exploitation], in T. Bergqvist, G. Gillberg and L. Ivarsson (eds.) Arbete: Passion och Exploatering. [Work: Passion and Exploitation.] Arbetsliv i omvandling. Växjö: Linneuniversitetet, pp. 7-22. 
Karlsson, J. Ch. (2015) 'Work, Passion, Exploitation'. Nordic journal of working life studies, 2(5): 1-14.

Korpi, W. (1978) Arbetarklassen i välfärdskapitalismen. [Working Class in the Welfare Capitalism.] Stockholm: Prisma i samarbete med Institutionen för social forskning.

Kosík, K. (1976) Dialectics of the Concrete. Dordrecht: D. Riedel.

Kronauer, M. (1998) “"Social Exclusion” and "Underclass"-New Concepts for the Analysis of Poverty', in H.-J. Andre (ed.), Empirical Poverty Research in a Comparative Perspective. Aldershot, England: Ashgate, pp. 51-75.

Marsden, P. V., A. L. Kalleberg \& C. R. Cook (1993) 'Gender Differences in Organisational Commitment: Influences of Work Positions and Family Roles'. Work and Occupations, 3(20): 368-390.

Nordenmark, M. (1999) 'Employment Commitment and Psychological Well-Being among Unemployed Men and Women'. Acta Sociologica, 42(2): 135-149.

Starrin, B., L. R. Jönsson. \& U. Rantakeisu (2001) ‘Sense of Coherence during Unemployment'. International Journal of Social Welfare, 10: 107-116.

Svallfors, S., K. Halvorsen \& J. G. Andersen (2001) 'Work Orientations in Scandinavia: Employment Commitment and Organizational Commitment in Denmark, Norway and Sweden'. Acta Sociologica, 44: 139-156.

Tilly, Charles (1998) Durable Inequality. Berkeley: University of California Press.

Tolbert, P. \& P. Mohen (1998) 'Men's and Women's Definitions of “Good” Jobs: Similarities and Differences by Age and Across Time’. Work and Occupations, 25: 168-194.

\section{End note}

${ }^{1}$ Results presented in this article have been obtained within the project 'Youth, Unemployment, and Exclusion in Europe: A Multidimensional Approach to Understanding the Conditions and Prospects for Social and Political Integration of Young Unemployed' (YOUNEX). This project was funded by the European Commission under the 7th Framework Program (grant agreement No. 216122). Part of the results of his article originates from a report produced within this project: 'WP3 Report. Integrated Report on Individual Survey.' Deliverable no 10.2011 . 